
Kidney
Blood Pressure
Research

\title{
The Intron 4 Polymorphism in the Calcium- Sensing Receptor Gene in Diabetes Mellitus and its Chronic Complications, Diabetic Nephropathy and Non-Diabetic Renal Disease
}

\author{
Viera Železníkováab Marcela Vedralováa Anna Kotrbová-Kozaka \\ Hana Zoubkováa Marie Černáa Ivan Rychlík ${ }^{b}$ \\ aept. of General Biology and Genetics and ' 2 2nd Dept. of Internal Medicine, Third Faculty of Medicine, \\ Charles University in Prague, Czech Republic
}

\section{Key Words}

Diabetes Mellitus • Diabetic Nephropathy $•$ Calcium-Sensing Receptor • Polymorphism

\begin{abstract}
Background/Aims: Calcium-Sensing Receptor (CaSR) significantly affects calcium-phosphate metabolism in kidneys, and it is implicated in the pathogenesis of diabetes mellitus (DM) due to its expression in pancreatic $\beta$-cells. The role of CaSR as one of the players in pathogenesis of chronic kidney disease (CKD) has been speculated. Methods: 158 Type 2 diabetic patients divided into three groups according to occurrence and type of kidney complications, 66 nondiabetic patients CKD, and 93 healthy subjects were enrolled into the study to analyze the role of two CaSR polymorphisms (in the codon 990 and in the intron 4) in ethiopathogenesis of DM and CKD. The Type 2 diabetic groups consisted of 48 patients without any kidney abnormalities, 58 patients with diabetic nephropathy (DN), and 52 patients with nondiabetic renal disease (NDRD). The distribution of genotype and allele frequencies was studied using PCR with the TaqMan Discrimination Assay or followed by the Restriction Fragment Length Polymorphism method, respectively. Results: We have found that the intron 4 polymorphism is a risk factor for the development of DM and CKD, except DN, while the codon 990 does not show any disease association. Conclusion: We conclude that CaSR is a general factor in pancreas and kidney pathologies.
\end{abstract}




\section{Kidney Blood Pressure Research}

Kidney Blood Press Res 2014;39:399-407

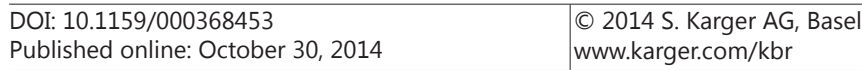

Železníková/Vedralová/Kotrbová-Kozak/Zoubková/Černá/Rychlík: CaSR Gene in Diabetic Nephropathy

\section{Introduction}

Diabetes mellitus (DM) belongs among one of the most common life-style diseases. Its complication, diabetic nephropathy (DN), represents the leading cause of end-stage renal disease worldwide. The pathogenesis of DN has many genetic and environmental factors contributing to its development and progression. DN is the main cause of end-stage renal disease in developed countries and about $80 \%$ of these patients have Type 2 diabetes [1]. It has also been described as familial aggregation for diabetic nephropathy. A number of genetic variants have been reportedly associated with diabetic nephropathy in recent years. Some have been identified by genome-wide association and linkage analysis, [2] whereas others have been examined because of their potential role in the pathogenesis of diabetic nephropathy [3].

Compared to other forms of chronic kidney disease (CKD), DN is associated with a higher prevalence of chronic kidney disease-mineral bone disorder (CKD-MBD), as well as its more common adynamic form. The reasons for this epidemiology pattern are not entirely clear. It was concluded that there is a significant correlation between the state of metabolic normalization of diabetes and the degree of biochemical aberrations concerning calciumphosphate metabolism [4]. The calcium homeostasis in diabetic patients with normal renal function is very stable, despite the fact that decreased response of parathyroid hormone to phosphate loading was described [5].

The role of the extracellular calcium-sensing receptor (CaSR) in general calcium homeostasis is now well established [6, 7]. In the kidneys, CaSR is expressed in the cells lining the distal part of the kidney tubules. There, calcium reabsorption occurs through the paracellular route, driven by a small positive charge of the tubular lumen relative to the interstitial fluid. This small positive charge depends on active sodium-potassium-chloride reabsorption, which is accompanied by some potassium backflow. The binding of calcium to CaSR inhibits active sodium-potassium-chloride reabsorption and thus also calcium reabsorption. The presence of a functional CaSR on human pancreatic B-cells suggests that these cells respond to changes of extracellular calcium cations concentrations $[8,9]$.

However, it is not known yet by which mechanism(s) vitamin D and calcium can interfere with the induction of insulin resistance at the systemic or at the target cell level. Furthermore, the association of CaSR polymorphisms with parathyroid hormone (PTH) secretion as well as the extent of the progression of secondary hyperparathyroidism were reported in Japanese hemodialysis patients [10]. Compared to other genotypes, the progression of hyperparathyroidism in predialysis patients with vitamin D receptor (VDR) BB genotypes is slowed down. Also, the calcitriol level is more pronounced in the BB genotype, which may act to lessen the severity of secondary hyperparathyroidism [11]. However, the polymorphism in the intron 5 of the CaSR gene does not appear to be associated with non-insulin dependent diabetes mellitus [12]. Furthermore, the functional importance of CaSR in calcium metabolism is demonstrated on monogenic diseases. Familial hypocalciuric hypercalcemia is caused by mutations in the CaSR gene [13].

We hypothesized that the genetic background should also be considered as playing a role in calcium-phosphate metabolism in DM and its chronic kidney complications. Thus, the aim of the study was to investigate two polymorphisms (one in coding and one in regulatory regions) of the CaSR gene with respect to ethiopathogenesis of DN and Non-Diabetic Renal Disease (NDRD) in Type 2 diabetic patients.

\section{Materials and Methods}

Subject

Only Type 2 diabetic patients were enrolled into the study. They were divided into 3 groups: the group of patients without any signs of kidney abnormalities or kidney disease (DM2), the group of patients with 


\section{Kidney \\ Blood Pressure Research}

Kidney Blood Press Res 2014;39:399-407

\begin{tabular}{l|l}
\hline DOI: $10.1159 / 000368453$ & C 2014 S. Karger AG, Basel
\end{tabular}

Publisned ontrne: Uctober 30, 2014

www.karger.com/kbr

Železníková/Vedralová/Kotrbová-Kozak/Zoubková/Černá/Rychlík: CaSR Gene in Diabetic Nephropathy

diabetic nephropathy (DN), the group of patients with non-diabetic renal disease (NDRD). Two control groups were included- nondiabetic patients with CKD (NWD) and healthy subjects without any signs of nephropathy and diabetes. All studied groups are matched by age and sex.

The diagnosis of diabetes was made according to ADA criteria [14]. Diagnostic criteria for the definitions of nephropathy type were applied according to the clinical - laboratory characteristics (Table 1). The DN group was consisted of patients fulfilling the slightly modified NKF criteria [15]: the duration of DM for as little as 10 years, 24-hour proteinuria $>2.0 \mathrm{~g}$, normal kidney size ( $>110 \mathrm{~mm}$ in longitudinal diameter on ultrasound examination performed in the last 6 months), and the presence of diabetic retinopathy of any grade. The NDRD group criteria were the following: the duration of DM for as little as 10 years, normoalbuminuria ( $<30 \mathrm{mg} / 24$-hour), reduced kidney size $(<110 \mathrm{~mm}$ in longitudinal diameter on ultrasound examination performed in last 6 months), and the absence of diabetic retinopathy. Furthermore, for the equality of patients, only the patients with CKD stage 2-4 were included in both groups. The control NWD group was characterized by the presence of any type of CKD, and no DM. Healthy controls were collected from blood donor volunteers.

The study was approved by the Ethical Committees of the Third Faculty of Medicine, Charles University in Prague. Written informed consent was obtained from all study subjects.

\section{Genotyping}

Genomic DNA was extracted from the whole peripheral blood using the salting out method described previously [16].

The genotyping of the codon 990 polymorphism A/G (rs1042636) was performed by the TaqMan Discrimination Assay (Applied Biosystems, Foster City, CA) on a 7500 Fast Real Time system. The thermal cycle conditions were as follows: initial denaturating at $95^{\circ} \mathrm{C}$ for $10 \mathrm{~min}$, followed by 40 cycles of denaturating at $92^{\circ} \mathrm{C}$, and annealing and extension at $60^{\circ} \mathrm{C}$ for $1 \mathrm{~min}$. Data were measured and analyzed using the 7500 Software Package v 2.0.1.

The DNA fragment including the intron 4 polymorphism (rs3804594) was identified by the polymerase chain reaction followed by the restriction fragment length polymorphism (PCR/RFLP) methods. The forward and reverse primers used to amplify the locus within the intron 4 polymorphism were 5'-CAAGGACCTCTGGACCTCCCTTTGC-3' and 5'-GACCAAGCCCTGCACAGTGCCCAAG-3', as were previously described [17]. The PCR amplification was performed in a $25 \mu$ total reaction volume containing 20-50 ng/ $\mu \mathrm{l}$ DNA template, $1.5 \mathrm{mM} \mathrm{MgCl}, 2 \mathrm{mM}$ dNTP, $100 \mathrm{pmol} / \mathrm{ul}$ of each primer, $1 \mathrm{U}$ Taq DNA polymerase and $1 \mathrm{x}$ $\mathrm{NH}_{4}\left(\mathrm{SO}_{2}\right)_{2} \mathrm{PCR}$ reaction buffer (all from Fermentas, Canada). The PCR program followed: $94^{\circ} \mathrm{C}$ for 5 min $(1$ cycle), $94^{\circ} \mathrm{C}$ for $30 \mathrm{sec}, 68^{\circ} \mathrm{C}$ for $30 \mathrm{sec}$, with a final extension $72^{\circ} \mathrm{C}$ for $5 \mathrm{~min}$ ( 35 cycles). The $320 \mathrm{bp} \mathrm{long} \mathrm{PCR}$ product was digested overnight with BseRI, separated on $3 \%$ agarose gel and visualized by GelRed (Biotium, USA) staining. Genotypes were determined as major homozygote TT (320 bp), minor homozygote CC (260 and $60 \mathrm{bp})$, and heterozygote TC (320, 260 and $60 \mathrm{bp})$.

\section{Statistical Analysis}

The statistical analysis was performed using GraphPad Prism 5. 04 software. Comparison between groups was determined with Fisher's exact two-tailed test. Differences among groups were considered statistically significant if $\mathrm{P}<0.05$. Relative risk was estimated by calculating the odds ratio (OR) and $95 \%$ confidence interval $(95 \% \mathrm{CI})$.

\section{Results}

The groups analyzed in this study consisted of: A)158 type 2 diabetic patients divided into three groups according to occurrence and type of kidney complications B) 66 nondiabetic patients with CKD, and C)93 healthy subjects. All individual groups were studied to analyze a role of two CaSR polymorphisms in ethiopathogenesis of diabetes mellitus, diabetic nephropathy and chronic kidney disease. Basic clinical laboratory characteristics of all groups are given in Table 1. 


\section{Kidney \\ Blood Pressure \\ Research}

Frequencies of the codon 990 polymorphism are shown in Table 2. Genotype and allele frequencies in each group of patients were compared with healthy subjects and nondiabetic patients with CKD (the NWD group). We did not find any statistical differences between the analyzed groups in genotype (AA, AG, GG) or allele $(A, G)$ frequencies of the codon 990 ,
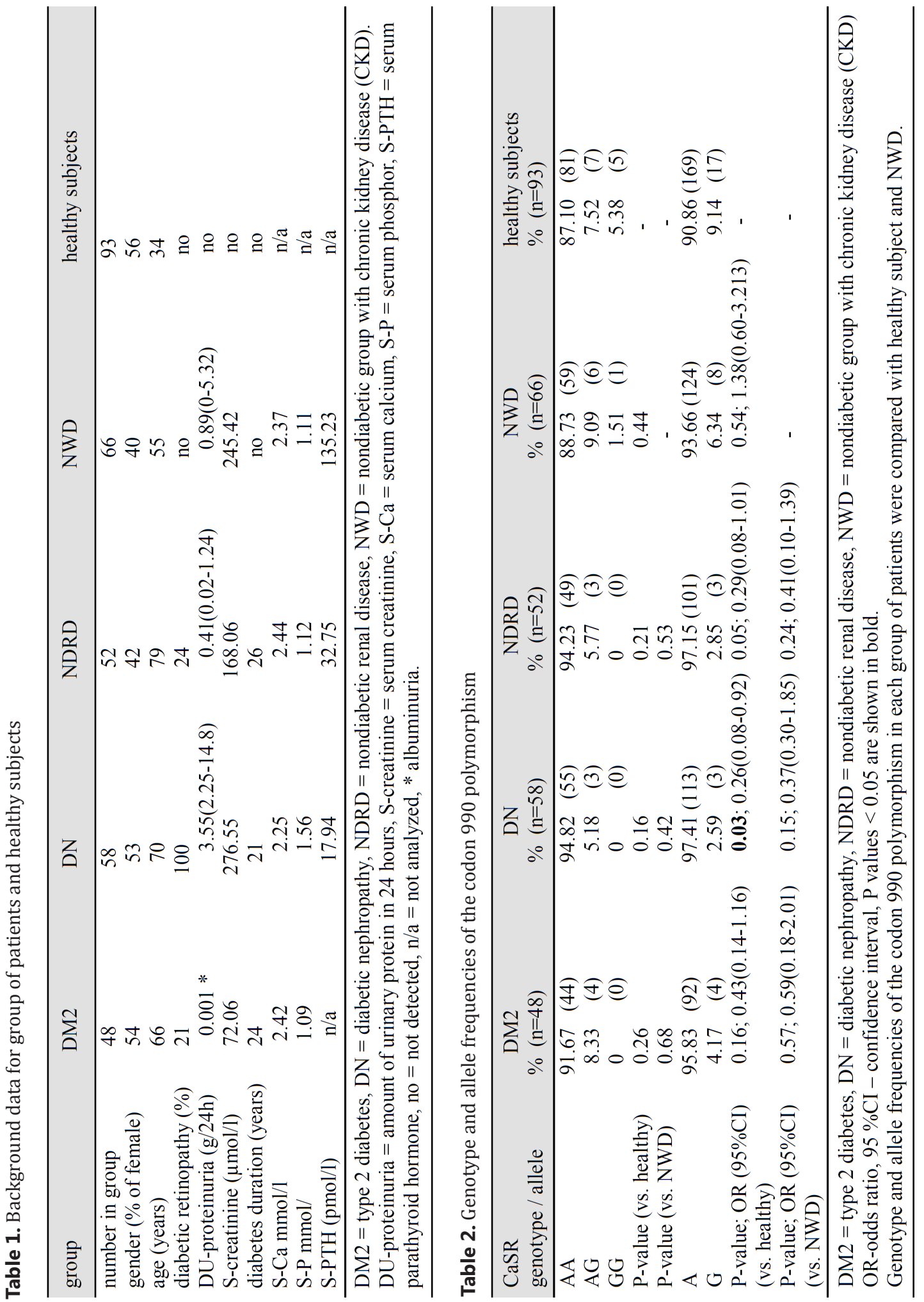


\section{Kidney \\ Blood Pressure Research}

except one - we observed very moderate borderline statistically significant allele difference in the DN group compared to healthy subjects $(\mathrm{P}=0.03)$.

Frequencies of the intron 4 polymorphism are shown in Table 3. As in the first polymorphism, genotype and allele frequencies in each group of patients were compared with healthy subjects and nondiabetic patients with CKD (the NWD group). We have found statistically significant differences of the genotype (CC, TC, TT) frequencies of the intron 4 in each group of patients (diabetic and nondiabetic) compared to healthy subjects, except

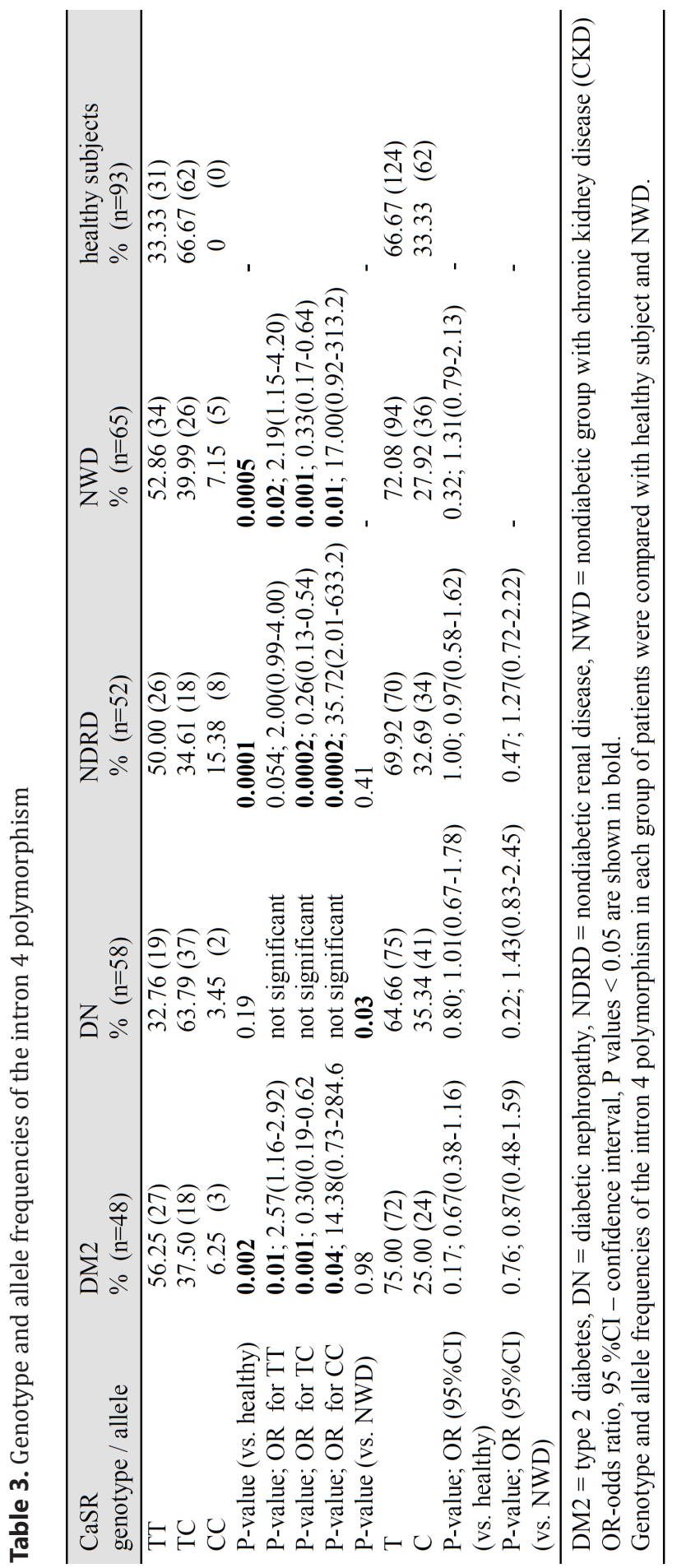

DN. The statistical values were for the NDRD group: $\mathrm{P}=0.0001$, $\mathrm{OR}(\mathrm{CC})=36, \mathrm{OR}(\mathrm{TT})=2$; for the NWD group: $\mathrm{P}=0.0005, \mathrm{OR}(\mathrm{CC})=$ $17, \mathrm{OR}(\mathrm{TT})=2$; and for the DM2 group: $\mathrm{P}=0.002, \mathrm{OR}(\mathrm{CC})=14$, $\mathrm{OR}(\mathrm{TT})=3$. The heterozygote genotype seems to be protective in all mentioned groups, $\mathrm{OR}(\mathrm{TC})=$ 0.3 . The comparisons of diabetic patients with the NWD group did not show any statistical significance in genotype frequencies except one - very moderate borderline statistically significant difference in the DN group $(P=0.03)$. It suggests the intron 4 polymorphism is a risk factor for Type 2 diabetes mellitus and chronic kidney diseases, but not for DN. On the other hand, there were no statistically significant differences in the allele $(\mathrm{T}, \mathrm{C})$ frequencies of the intron 4 polymorphism in all groups of patients compared to the NWD group or healthy subjects.

The laboratory values of serum calcium (Ca), phosphor (P) and parathyroid hormone (PTH) did not differ significantly between groups, and they are all in the physiological range.

According to the Czech law, all blood donors are routinely strip checked for serum creatinine, and urine biochemistry (glucose, proteins) and sediment (erythrocytes, leucocytes), which must be in the physiological range. For this reason we did not examine the exact single individual value of each blood donor. 


\section{Kidney Blood Pressure Research}

Kidney Blood Press Res 2014;39:399-407

\begin{tabular}{l|l}
\hline DOI: $10.1159 / 000368453$ & (C) 2014 S. Karger AG, Basel
\end{tabular}

Publisned ontine: October 30, 2014

www.karger.com/kbr

Železníková/Vedralová/Kotrbová-Kozak/Zoubková/Černá/Rychlík: CaSR Gene in Diabetic Nephropathy

\section{Discussion}

In the present study, we examined the role in which selected variants of the CaSR gene would play in the susceptibility of individuals for Type 2 diabetes mellitus, DN and NDRD. We compared the genotype and allele frequencies between each group of patients and healthy subjects (for detection predisposition in general), and between each group of patients and nondiabetic patients with CKD (for proving if the predisposition is linked only to diabetes and its kidney complications, or if it is directly linked to kidney diseases at all).

As far as the type of nephropathy is concerned, most of the patients did not undergo the renal biopsy (RB) which is infrequently indicated in the patients with suspected diabetic glomerulosclerosis or with peripheral vascular nephrosclerosis as primary renal disease. It is well known that these entities can be present concomitantly, or can overlap each other. That is why we decided to tighten up the criteria for DN (duration of DM > $10 \mathrm{yrs}$, minimum $2.0 \mathrm{~g}$ 24-hr proteinuria vs. normoalbuminuria, definition of normal kidney size vs. decreased size, and absolute vs. none presence of DR). Nevertheless, of course, other primary glomerulopathies can occur in diabetic patients, too, clinically presented as e.g. nephritic syndrome, but it is a very uncommon long lasting course of these kinds of disease (i.e. > 10 yrs) as is true for DN. Thus we believe that the type of nephropathy was defined as the best as it is realistic on routine clinical settings using the definition criteria even more precisely like the other authors did $[18,19]$.

In this study, we have found the intron 4 polymorphism of the CaSR gene is a risk factor for Type 2 diabetes mellitus and CKD, but not for DN. Therefore we hypothesize its protective role for diabetic microvascular complication. The predisposition to kidney diseases seems to be diabetes itself independent. Since the predisposed polymorphism is located in the regulation region, it should correlate with different gene expression levels.

It is of interest that we did not observe any statistically significant differences in the laboratory values of serum calcium, phosphor and parathyroid hormone. One of the reasons can be moderate CKD or proper therapy of $\mathrm{Ca}-\mathrm{P}-\mathrm{PTH}$ abnormalities.

CaSR was described in 1993 [20]. It was found that it is expressed in the kidney, thyroid gland, placenta, bone, intestinal epithelial cells, and also in the tissues unrelated to calcium homeostasis, such as the brain, pancreas, heart, skin, and many others, so it is now known to serve as a multifunctional receptor. Heterozygous inactivating mutations of the CaSR gene lead to the familial hypocalciuric hypercalcemia [21], but not in all cases. Homozygous inactivating mutations of CaSR give rise to neonatal severe hyperparathyroidism. Activating mutations of CaSR result in autosomal dominant hypocalcemia [22], and over 80 mutations associated with this disorder have been documented. CaSR is considered to play a central role in the pathogenesis of primary, to some extent secondary, hyperparathyroidism [23]. It has the effects on the secretion of parathyroid hormone-related peptide and impact on humoral hypercalcemia of malignancy [24]. There are a few documented cases of neurodegenerative disease linked to dysfunctional CaSR expression [25].

Three single nucleotide polymorphisms (SNPs) - Ala986Ser (G/T), Arg990Gly (A/G), Gln $1011 \mathrm{Glu}(\mathrm{C} / \mathrm{G})$ - in the exon 7, encoding the CaSR intracellular domain, are the predominant ones that have been examined. It was found that the Arg990Gly intracellular polymorphism could increase Ca excretion and susceptibility to idiopathic hypercalciuria by facilitating the activation of CaSR [26]. Furthermore, all three polymorphisms were associated with idiopathic recurrent calcium urolithiasis [27]. However, calcium kidney stone formation was also associated with six other SNPs in the promoter region of the CaSR gene [28]. On the other hand, the report on the relation of CaSR and the development of valvular calcification in chronic hemodialysis patients did not prove the role of CaSR gene polymorphisms in the valvular calcification etiology [29].

CaSR appears to protect against cardiac hypertrophy thanks to its expression in neonatal and adult cardiomyocytes, and it is also presented in perivascular nerves of the adventitia. Vascular smooth muscle cells and endothelial cells link it to vasodilatation and the regulation 


\section{Kidney \\ Blood Pressure Research}

Kidney Blood Press Res 2014;39:399-407

\begin{tabular}{l|l}
\hline DOI: $10.1159 / 000368453$ & C 2014 S. Karger AG, Basel
\end{tabular}

Published onlıne: October 30, 2014

www.karger.com/kbr

Železníková/Vedralová/Kotrbová-Kozak/Zoubková/Černá/Rychlík: CaSR Gene in Diabetic Nephropathy

of arterial blood pressure [30]. CaSR also exerts control over the renin-angiotensin system which governs blood pressure and extracellular volume [31].

The study in the animal model of Type 2 diabetes, Zucker diabetic fatty (ZDF) rats, found that vascular CaSR was down regulated in the mesenteric arteries. Its activation led to vasorelaxation. Therefore in Type 2 diabetic patients, CaSR could be one of the predisposition factors for vascular complications, because the suppression of the CaSR pathway favors the long-term development of higher basal vascular tone [32].

In the review of Ward et al. from 2012, the expression of CaSR in both endocrine and exocrine human pancreas is mentioned. L-histidine induced activation of CaSR could inhibit insulin secretion in pancreatic beta cells, induced by glucose, through the CaSR spatial rearrangement and voltage-dependent calcium channels. In contrary to vascular complications, activation of the CaSR pathway favors the development of diabetes. These facts are in agreements with our results in DM and DN patients [33].

The strengths of our study design are the precise definition of a single analyzed group and the tightened criteria for 24 -hr proteinuria (minimum $2.0 \mathrm{~g}$ ). We were limited by smaller sizes of analyzed groups (it would have been nice to have had larger) and the definition of nephropathy, which was performed on the base of clinical laboratory settings.

\section{Conclusion}

We have found that the intron 4 polymorphism of the CaSR gene is a risk factor for Type 2 diabetes mellitus and chronic kidney diseases, but not for DN. There seems to be no correlation between the predisposition to kidney diseases and diabetes.

\section{Disclosure statement}

The authors of this manuscript have no conflicts of interests.

\section{Acknowledgements}

This study was financially supported by the Research program of Charles University in Prague: 260042/SVV/2014. A.K.K. and H.Z. gratefully acknowledge support of the Charles University in Prague through University Research Centre program UNCE 204015.

\section{References}

1 Kahn CR, Weir GC, King GL, Jacobson AM, Moses AC, Smith RJ: Joslin’s Diabetes Mellitus, 14th edition. Lippincott Williams \& Wilkins, Boston 2005.

-2 Pezzolesi MG, Poznik GD, Mychaleckyj JC, Paterson AD, Barati MT, Klein JB, Ng DP, Placha G, Canani LH, Bochenski J, Waggott D, Merchant ML, Krolewski B, Mirea L, Wanic K, Katavetin P, Kure M, Wolkow P, Dunn JS, Smilek A, Walker WH, Boright AP, Bull SB; DCCT/EDIC Research Group, Doria A, Rogus JJ, Rich SS, Warram JH, Krolewski AS: Genome-wide association scan for diabetic nephropathy susceptibility genes in type 1 diabetes. Diabetes 2009;58:1403-1410.

-3 Gu HF, Brismar K: Genetic association studies in diabetic nephropathy. Curr Diabetes Rev 2012;8:336-344.

4 Błasiak M, Kuska J, Kokot F, Irzyniec T: Selected indicators of calcium-phosphate metabolism in patients with diabetes mellitus. Endokrynol Pol 1989;40:251-262. 


\section{Kidney \\ Blood Pressure Research}

5 Kawagishi T, Sekiya K, Okuno Y, Miki T, Nishizawa Y, Morii H: Calcium metabolism in diabetes mellitus. J Nutr Sci Vitaminol (Tokyo) 1991;37:S51-56.

6 Hofer AM, Brown EM: Extracellular calcium sensing and signaling. Nat Rev Mol Cell Biol 2003;4:530-538.

7 Breitwieser GE: The calcium sensing receptor life cycle: trafficking, cell surface expression, and degradation. Best Pract Res Clin Endocrinol Metab 2013;27:303-313.

8 Squires PE, Harris TE, Persaud SJ, Curtis SB, Buchan AM, Jones PM: The extracellular calcium-sensing receptor on human beta-cells negatively modulates insulin secretion. Diabetes 2000;49:409-417.

-9 Yang SN, Berggren PO: Beta-cell CaV channel regulation in physiology and pathophysiology. Am J Physiol Endocrinol Metab 2005;288:E16-28.

10 Yano S, Sugimoto T, Tsukamoto T, Chihara K, Kobayashi A, Kitazawa S, Maeda S, Kitazawa R: Association of decreased calcium-sensing receptor expression with proliferation of parathyroid cells in secondary hyperparathyroidism. Kidney Int 2000;58:1980-1986.

11 Degenhardt S, Toell A, Weidemann W, Dotzenrath C, Spindler KD, Grabensee B: Point mutations of the human parathyroid calcium receptor gene are not responsible for non-suppressible renal hyperparathyroidism. Kidney Int 1998;53:556-561.

12 Koishi S, Aida K, Tawata M, Onaya T: Polymorphism of the human Ca(2+)-sensing receptor gene in Japanese individuals: no relation to non-insulin dependent diabetes mellitus. Horm Metab Res 1996;28:541-544.

13 Aida K, Koishi S, Inoue M, Nakazato M, Tawata M, Onaya T: Familial hypocalciuric hypercalcemia associated with mutation in the human $\mathrm{Ca}(2+)$-sensing receptor gene. J Clin Endocrinol Metab 1995;80:2594-2598.

14 World Health Organisation Definition: Diagnosis and Classification of Diabetes Mellitus and its Complication, Report of a WHO Consultation. Part 1: Diagnosis and Classification of Diabetes Mellitus. Geneva 1999.

15 KDOQI (Kidney Disease Outcome Quality Initiative): Clinical practice guidelines and clinical practice recommendations for diabetes and chronic kidney disease. Am J Kidney Dis 2007;49:S12-154.

16 Miller SA, Dykes DD, Polesky HF: A simple salting out procedure extracting DNA from human nucleated cells. Nucleic Acids Res 1988;16:1215-1215.

17 Yano S, Sugimoto T, Kanzawa M, Tsukamoto T, Hattori T, Hattori S, Chihara K: Association of Polymorphic Alleles of the Calcium-Sensing Receptor Gene with Parathyroid Hormone Secretion in Hemodialysis Patients. Nephron 2000;85:317-323.

18 Janssen B, Hohenadel D, Brinkkoetter P, Peters V, Rind N, Fischer C, Rychlik I, Cerna M, Romzova M, de Heer E, Baelde H, Bakker SJL, Zirie M, Rondeau E, Mathieson P, Saleem MA, Meyer J, Köppel H, Sauerhoefer S, Bartram CR, Nawroth P, Hammes HP, Yard BA, Zschocke J, van der Woude FJ: Carnosine as a protective factor in diabetic nephropathy: Association with a leucine repeat of the carnosinase gene CNDP1. Diabetes 2005;54:2320-2327.

19 Alkhalaf A, Zürbig P, Bakker SJL, Bilo HJG, Cerna M, Fischer C, Fuchs S, Janssen B, Medek K, Mischak H, Roob JM, Rossing K, Rossing P, Rychlík I, Sourij H, Tiran B, Winklhofer-Roob BM, Navis GJ: Multicentric validation of proteomic biomarkers in urine specific for diabetic nephropathy. PLoS One 2010;5:e13421.

20 Brown EM, Gamba G, Riccardi D, Lombardi M, Butters R, Kifor O, Sun A, Hediger MA, Lytton J, Hebert SC: Cloning and characterization of an extracellular $\mathrm{Ca}(2+)$-sensing receptor from bovine parathyroid. Nature 1993;366:575-580.

21 Pollak MR, Brown EM, Chou YH, Hebert SC, Marx SJ, Steinmann B, Levi T, Seidman CE, Seidman JG: Mutations in the human $\mathrm{Ca}(2+)$-sensing receptor gene cause familial hypocalciuric hypercalcemia and neonatal severe hyperparathyroidism. Cell 1993;75:1297-1303.

22 Pollak MR, Brown EM, Estep HL, McLaine PN, Kifor O, Park J, Hebert SC, Seidman CE, Seidman JG: Autosomal dominant hypocalcaemia caused by a $\mathrm{Ca}(2+)$-sensing receptor gene mutation. Nat Genet 1994;8:303-307.

23 Scillitani A, Guarnieri V, Battista C, De Geronimo S, Muscarella LA, Chiodini I, Cignarelli M, Minisola S, Bertoldo F, Francucci CM, Malavolta N, Piovesan A, Mascia ML, Muscarella S, Hendy GN, D’Agruma L, Cole DE: Primary hyperparathyroidism and the presence of kidney stones are associated with different haplotypes of the calcium-sensing receptor. J Clin Endocrinol Metab 2007;92:277-283.

24 Chattopadhyay N: Effects of calcium-sensing receptor on the secretion of parathyroid hormone-related peptide and its impact on humoral hypercalcemia of malignancy. Am J Physiol Endocrinol Metab 2006;290:E761-770. 


\section{Kidney \\ Blood Pressure Research}

Kidney Blood Press Res 2014;39:399-407

DOI: $10.1159 / 000368453$

Publisned onine: Uctober 30, 2014

(C) 2014 S. Karger AG, Basel

www.karger.com/kbr

Železníková/Vedralová/Kotrbová-Kozak/Zoubková/Černá/Rychlík: CaSR Gene in Diabetic Nephropathy

25 Conley YP, Mukherjee A, Kammerer C, DeKosky ST, Kamboh MI, Finegold DN, Ferrell RE: Evidence supporting a role for the calcium-sensing receptor in Alzheimer disease. Am J Med Genet B Neuropsychiatr Genet 2009;150B:703-709.

26 Vezzoli G, Tanini A, Ferrucci L, Soldati L, Bianchin C, Franceschelli F, Malentacchi C, Porfirio B, Adamo D, Terranegra A, Falchetti A, Cusi D, Bianchi G, Brandi ML: Influence of calcium-sensing receptor gene on urinary calcium excretion in stone-forming patients. J Am Soc Nephrol 2002;13:2517-2523.

-27 Shakhssalim N, Kazemi B, Basiri A, Houshmand M, Pakmanesh H, Golestan B, Eilanjegh AF, Kashi AH, Kilani M, Azadvari M: Association between calcium-sensing receptor gene polymorphisms and recurrent calcium kidney stone disease: a comprehensive gene analysis. Scand J Urol Nephrol 2010;44:406-412.

28 Vezzoli G, Terranegra A, Arcidiacono T, Gambaro G, Milanesi L, Mosca E, Soldati L; GENIAL network (Genetics and Environment in Nephrolithiasis Italian Alliance): Calcium kidney stones are associated with a haplotype of the calcium-sensing receptor gene regulatory region. Nephrol Dial Transplant 2010;25:2245-2252.

29 Turkmen F, Ozdemir A, Sevinc C, Eren PA, Demiral S: Calcium-sensing receptor gene polymorphisms and cardiac valvular calcification in patients with chronic renal failure: a pilot study. Hemodial Int 2009;13:176-180.

30 Smajilovic S, Tfelt-Hansen J: Calcium acts as a first messenger through the calcium-sensing receptor in the cardiovascular system. Cardiovasc Res 2007;75:457-467.

-31 Atchison DK, Ortiz-Capisano MC, Beierwaltes WH: Acute activation of the calcium-sensing receptor inhibits plasma renin activity in vivo. Am J Physiol Regul Integr Comp Physiol 2010;299:R1020-1026.

32 Weston AH, Absi M, Harno E, Geraghty AR, Ward DT, Ruat M, Dodd RH, Dauban P, Edwards G: The expression and function of $\mathrm{Ca}(2+)$-sensing receptors in rat mesenteric artery; comparative studies using a model of type II diabetes. Br J Pharmacol 2008;154:652-662.

-33 Ward BK, Magno AL, Walsh JP, Ratajczak T: The role of Calcium-sensing receptor in human disease. Clin Biochem 2012;45:943-953. 